\title{
GEIDST
}

\section{INFECÇÃO GENITAL POR CHLAMYDIA TRACHOMATIS E NEISSERIA GONORRHOEAE EM HOMENS ASSINTOMÁTICOS}

\author{
Nélia Cunha', Joana Cabete, Sara Campos², Ana Brasileiro', Vasco Serrão² \\ Dermatology Department, Centro Hospitalar de Lisboa Central, Lisboa, Portugal \\ IInterna do Internato Complementar de Dermatologia e Venereologia/Resident of Dermatology and Venereology, Serviço de \\ Dermatologia e Venereologia do Hospital S. António dos Capuchos, Centro Hospitalar Lisboa Central \\ ${ }^{2}$ Assistente Hospitalar Graduada de Dermatologia/Graduated Consultant of Dermatology and Venereology, Serviço de Dermatologia \\ e Venereologia do Hospital S. António dos Capuchos, Centro Hospitalar Lisboa Central \\ Serviço de Dermatologia, Hospital S. António dos Capuchos, Centro Hospitalar Lisboa Central, Lisboa, Portugal
}

RESUMO - Introdução: A infecção genital por Chlamydia trachomatis (CT) e Neisseria gonorrhoeae (NG) é frequente, sendo a infecção assintomática importante sobretudo no caso da CT. A disponibilidade de técnicas de amplificação de ácidos nucleicos de elevada sensibilidade e especificidade para o diagnóstico de infecção genital por estas bactérias levou à implementação do seu rastreio sistemático em Consultas de Infecções Sexualmente Transmissíveis (ISTs). Os autores pretenderam determinar a prevalência de infecção genital por CT e NG em homens assintomáticos numa Consulta de Venereologia e caracterizar a população testada. Métodos: Foi realizado um estudo retrospectivo em indivíduos do sexo masculino observados pela primeira vez na Consulta de Venereologia de um Serviço de Dermatologia em Lisboa, durante um período de 51 meses, rastreados para infecção genital assintomática por CT e NG. Resultados: Na população estudada $(n=199)$, a prevalência de infecção genital assintomática por CT e NG foi de $5 \%$ (10 doentes) e 0,5\% (1 doente), respectivamente. Verificou-se uma maior prevalência de infecção por CT nos heterossexuais $(7,7 \%$ vs $1,3 \%$ ) e a idade mediana do grupo dos infectados mostrou-se inferior, embora não estatisticamente significativa. Conclusão: A prevalência de $5,5 \%$ de infecção genital assintomática em homens encontrada no nosso estudo está de acordo com dados epidemiológicos de outros estudos e apoia as actuais recomendações em rastrear estas infecções na Consulta de ISTs.

PALAVRAS-CHAVE - Chlamydia trachomatis; Doenças dos Genitais Masculinos; Doenças Sexualmente Transmissíveis; Gonorreia; Infecções por Chlamydia; Neisseria gonorrhoeae.

\section{CHLAMYDIA TRACHOMATIS AND NEISSERIA GONORRHOEAE GENITAL INFECTION IN ASYMPTOMATIC MEN}

ABSTRACT - Introduction: Genital infection by Chlamydia trachomatis (CT) and Neisseria gonorrhoeae (NG) is common and may be asymptomatic, particularly for CT. The availability of nucleic acid amplification tests with high diagnostic sensibility and specificity allowed implementing routine screening in Sexually Transmitted Infections (STI) Clinics. We aimed to determine the prevalence of genital infection by these bacteria in asymptomatic men attending an STI Clinic in a Dermatology Department and to characterize this subpopulation. Methods: A retrospective 51-month-period study on male patients attending a STI Clinic in Lisbon and screened for asymptomatic genital infection by CT and NG was conducted. Data on demographics, sexual behavior, CT and NG screening results and other co-existing STIs were retrieved. Results: A total of 199 patients were analyzed. The prevalence of asymptomatic genital infection by CT and NG was 5\% (10 patients) and 0.5\% (1 patient), respectively. Asymptomatic genital infection by CT was higher in heterosexual men (7.8\% vs 1.3\%) and median age of the infected patients group was lower, although not statistically significant. Conclusion: Our study showed a prevalence of asymptomatic genital infection of $5.5 \%$ in male patients, which is in line with global epidemiologic data, thus further supporting the current recommendations on routine screening of these infections in the STI Clinic.

KEY-WORDS - Chlamydia infections; Chlamydia trachomatis; Genital Diseases, Male; Gonorrhea; Neisseria gonorrhoeae; Sexually Transmitted Diseases.

Conflitos de interesse: Os autores declaram não possuir conflitos de interesse. No conflicts of interest.

Suporte financeiro: $O$ presente trabalho não foi suportado por nenhum subsídio ou bolsa. No sponsorship or scholarship granted. Recebido/Received - Agosto/August 2015; Aceite/Accepted - Setembro/September 2015

Trabalho apresentado como Comunicação Oral no Congresso Nacional da SPDV 2014/Oral presentation at the National Congress $f$ the Portuguese Society of Dermatology. 


\section{GEIDST}

\section{Correspondência:}

Dr. ${ }^{a}$ Nélia Cunha

Serviço de Dermatologia e Venereologia

Hospital dos Capuchos - CHLC

Alameda S. António dos Capuchos

$1169-050$ - Lisboa, Portugal

Tel.: +351213136300 - Fax 213562208

Email: nelia.margarida.cunha@gmail.com

\section{INTRODUCTION AND OBJECTIVES}

Chlamydia trachomatis (CT) and Neisseria gonorrhoeae (NG) infections are the two most common sexually transmitted bacterial diseases worldwide.1,2 These infections may be asymptomatic, particularly for CT, and may be associated with complications and sequelae when left untreated. ${ }^{1-3}$ Nucleic acid amplification tests (NAATs) are nowadays available for the diagnosis, and their high sensibility and specificity allow for routine asymptomatic screening, which is indicated in specific situations. ${ }^{3,4}$ Concerning sexually active women, Centers for Disease Control and Prevention (CDC) Treatment Guidelines of Sexually Transmitted Diseases ${ }^{3}$ recommends annual CT and NG screening when below 25 years-old and in older women if at increased risk for infection. In men, cost-effectiveness of systematic screening is still controversial. ${ }^{3,5} \mathrm{CT}$ screening is recommended to be targeted and considered specifically when prevalence is high, resources permit, and it does not hamper CT screening in women; NG should only be tested in high risk settings. ${ }^{3}$

One of the clinical settings in which the high prevalence of these infections may justify routine screening in men is the STI Consultation. ${ }^{3,6}$ We aimed to determine the prevalence of genital infection by CT and NG in asymptomatic men attending the STI Clinic of our Dermatology Department in order to determine whether this screening should be maintained.

\section{METHODS}

A retrospective study was performed on male patients attending the STI Clinic of the Dermatology Department of Hospital de Santo António dos Capuchos, in Lisbon, between July 2010 and September 2014. Screening for CT and NG genital infection was requested to all patients on first visit. Diagnostic screening tests in men were performed on first-void urine using polymerase chain reaction assays. All male patients without symptoms of urethritis, with available CT/NG screening results, were included and analyzed. Data on socio-demographics, sexual behavior, and other co-existing STIs was also collected.

\section{RESULTS}

A total of 199 male patients with no clinical manifestation of urethritis were screened for CT and NG during the study period. Median age was 36 years old and $76.4 \%$ were

\section{NAAT results}

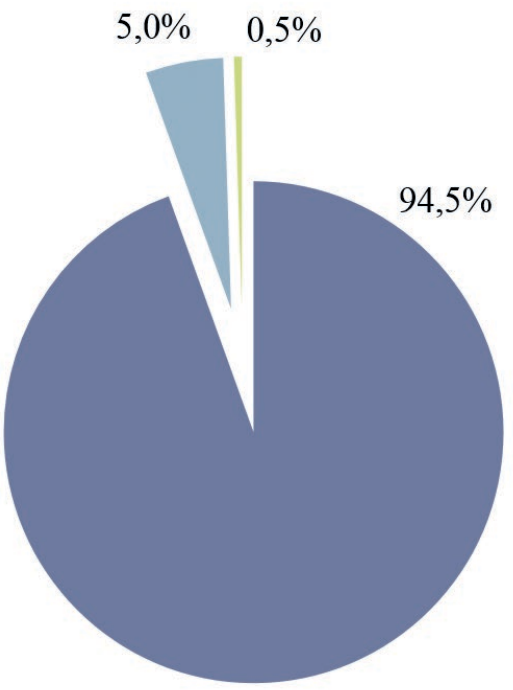

n CT/NG negative: 188 patients (94,5\%)

n CT positive: 10 patients $(5 \%)$

NG positive: 1 patient $(0,5 \%)$

Fig 1 - NAAT results for CT and NG infection on first-void urine $(n=199)$.

Portuguese patients (Table 1). Education level corresponding to high school or university was present in $52.3 \%$. Men who have sex with men (MSM) represented $38.7 \%$ of this population and $25.1 \%$ of the patients were human immunodeficiency virus (HIV) infected. Almost $50 \%$ mentioned one or no partner in the last 6 months, and $66.3 \%$ did not use condom or used it occasionally. The two main reasons for consultation were condyloma acuminata (36.7\%) and syphilis (24.7\%).

The determined prevalence of asymptomatic genital infection by CT and NG was 5\% (10 patients) and $0.5 \%$ ( 1 patient), respectively. Age tended to be lower in the infected group (28 vs 36 years-old). Asymptomatic genital infection by CT was 
Table 1 - Data on demographics, sexual behavior and reason for attending of the patients fulfilling inclusion criteria $(n=199)$.

\begin{tabular}{|c|c|}
\hline \multicolumn{2}{|c|}{ AGE (YEARS) } \\
\hline $\begin{array}{l}\text { Median (P25; P75) } \\
\text { Minimum - maximum }\end{array}$ & $\begin{array}{c}36(28 ; 45) \\
16-77\end{array}$ \\
\hline \multicolumn{2}{|c|}{ NATIONALITY (\%) } \\
\hline $\begin{array}{l}\text { Portuguese } \\
\text { Brazilian } \\
\text { Other }\end{array}$ & $\begin{array}{l}76.4 \\
12.1 \\
11.5\end{array}$ \\
\hline \multicolumn{2}{|c|}{ EDUCATION LEVEL (\%) } \\
\hline $\begin{array}{l}\text { No education } \\
\text { Primary school } \\
\text { Secondary school } \\
\text { High school } \\
\text { University } \\
\text { Unknown }\end{array}$ & $\begin{array}{c}0.5 \\
8.5 \\
25.6 \\
30.7 \\
21.6 \\
13.1\end{array}$ \\
\hline \multicolumn{2}{|c|}{ NUMBER OF PARTNERS IN THE PREVIOUS 6 MONTHS (\%) } \\
\hline $\begin{array}{l}0 \\
1 \\
2-3 \\
4-5 \\
>5 \\
\text { Unknown }\end{array}$ & $\begin{array}{c}7 \\
42.2 \\
25.1 \\
111 \\
11.1 \\
3.5\end{array}$ \\
\hline \multicolumn{2}{|c|}{ CONDOM (\%) } \\
\hline $\begin{array}{l}\text { Yes } \\
\text { No/Ocasionally } \\
\text { Unknown }\end{array}$ & $\begin{array}{l}27.1 \\
37.2 / 29.1 \\
6.5\end{array}$ \\
\hline \multicolumn{2}{|c|}{ SEXUAL ORIENTATION (\%) } \\
\hline $\begin{array}{l}\text { Heterosexual } \\
\text { MSM } \\
\text { Unknown }\end{array}$ & $\begin{array}{c}58.3 \\
38.7 \\
3\end{array}$ \\
\hline \multicolumn{2}{|c|}{ HIV INFECTED (\%) } \\
\hline $\begin{array}{l}\text { Yes: previously known } \\
\text { Yes: new diagnosis }\end{array}$ & $\begin{array}{c}23.6 \\
1.5\end{array}$ \\
\hline \multicolumn{2}{|c|}{ REASON FOR CONSULTATION (\%) } \\
\hline $\begin{array}{l}\text { Condyloma acuminata } \\
\text { Syphilis } \\
\text { Genital herpes } \\
\text { Candidal balanitis } \\
\text { Molluscum contagiosum } \\
\text { Other }\end{array}$ & $\begin{array}{c}36.7 \\
24.7 \\
8.5 \\
5.5 \\
3.5 \\
21.1\end{array}$ \\
\hline
\end{tabular}

higher in heterosexual $(7.8 \%$ vs $1.3 \%)$ and in HIV negative men $(6.2 \%$ vs $1.9 \%)$. These differences were not found to be statistically significant (Tables 2 and 3).

\section{DISCUSSION}

This study determined a total prevalence of asymptomatic male genital infection by CT or NG of $5.5 \%$, which supports continuation of routine screening in our STI Clinic. Nevertheless, asymptomatic genital infection by NG was only present
Table 2 - Prevalence of CT positive patients according to nationality, education, sexual orientation, sexual behaviour and HIV infection.

\begin{tabular}{|c|c|c|c|c|}
\hline & $\begin{array}{l}\text { CT (+) } \\
n=10\end{array}$ & $\begin{array}{c}\text { Population } \\
n=199\end{array}$ & $\begin{array}{c}\text { CT (+) } \\
\text { prevalence }\end{array}$ & value* \\
\hline $\begin{array}{l}\text { Portuguese } \\
\text { Other nationalities }\end{array}$ & $\begin{array}{l}6 \\
4\end{array}$ & $\begin{array}{c}152 \\
47\end{array}$ & $\begin{array}{c}4 \% \\
8.5 \%\end{array}$ & 0.251 \\
\hline $\begin{array}{l}\text { Highschool or university } \\
\text { Lower education }\end{array}$ & $\begin{array}{l}6 \\
4\end{array}$ & $\begin{array}{c}104 \\
69\end{array}$ & $\begin{array}{l}5.8 \% \\
5.8 \%\end{array}$ & 1.000 \\
\hline $\begin{array}{l}\text { MSM } \\
\text { Heterosexual }\end{array}$ & $\begin{array}{l}1 \\
9\end{array}$ & $\begin{array}{l}77 \\
116\end{array}$ & $\begin{array}{l}1.3 \% \\
7.8 \%\end{array}$ & 0.053 \\
\hline $\begin{array}{l}\text { HIV infected } \\
\text { Not HIV infected }\end{array}$ & $\begin{array}{l}1 \\
9\end{array}$ & $\begin{array}{c}54 \\
145\end{array}$ & $\begin{array}{l}1.9 \% \\
6.2 \%\end{array}$ & 0.292 \\
\hline $\begin{array}{l}\text { One or no partners (last } 6 \mathrm{mo} \text { ) } \\
\geq 2 \text { partners (last } 6 \text { months) }\end{array}$ & $\begin{array}{l}6 \\
4\end{array}$ & $\begin{array}{c}98 \\
101\end{array}$ & $\begin{array}{l}4.1 \% \\
5.9 \%\end{array}$ & 0.748 \\
\hline
\end{tabular}

Table 3 - Median age in CT infected and noninfected patients.

\begin{tabular}{|l|c|c|c|}
\hline & $\begin{array}{c}\mathbf{C T}(+) \\
\mathbf{n}=10\end{array}$ & $\begin{array}{c}\mathbf{C T}(\mathbf{-}) \\
\mathbf{n = 1 8 9}\end{array}$ & $\begin{array}{c}\mathbf{p} \\
\text { value* }\end{array}$ \\
\hline $\begin{array}{l}\text { Age, years } \\
\text { Median (P25; P75) }\end{array}$ & $\begin{array}{c}28(23.5 ; 39) \\
18-56\end{array}$ & $\begin{array}{c}36(28 ; 45) \\
16-77\end{array}$ & 0,072 \\
$\begin{array}{l}\text { Minimum - maximum } \\
\text { vinum }\end{array}$ & & & \\
\hline
\end{tabular}

*Mann-Whitney U Test

in 1 patient $(0.5 \%)$, as expected, since NG tends to present acutely. Currently, in our Institution, it is only possible to request a conjoint screening for NG and CT infection (with an approximate cost of 52 euros). If NG and CT testing become available as separated requests, the use of asymptomatic screening for NG is, in light of this data, more debatable and probably not cost-effective.

Prevalence of CT genital infection was higher in the heterosexual men group ( $7.7 \%$ vs $1.3 \%$ in the MSM group). This might relate to women's role as a reservoir for $\mathrm{CT}$, as asymptomatic genital infection is higher in women than in men. Moreover, routine screening of all young sexually active women is still not widely implemented in Portugal. This difference was not statistically significant, though. The low number of patients in the different subgroups might have limited the statistical significance of the study. Other limitation of our study is that these results are not representative of the sexual active Portuguese population and, therefore, cannot be extrapolated to other STI Clinics serving a different population.

Reviewing previously published literature, it is not unusual to debate with the lack of clear information on the prevalence of asymptomatic infections, as also recognized by 
Rietmeijer and colleagues. ${ }^{7}$ In addition, there are considerable methodological differences between studies. ${ }^{8}$ In European studies among sexually experienced patients, CT point prevalence estimates ranged from 0.76 to $5.9 \%$ in men less than 26 years old and from $1.4 \%$ to $6.9 \%$ in men aged 26 to 44 years-old. ${ }^{8}$ In the English National Chlamydia Screening Programme, ${ }^{9}$ where only patients under 25 years-old were included, there was a considerable heterogeneity between venues, with an overall CT positivity of $7.6 \%$ in men.

In one Iranian Urology Clinic, ${ }^{10}$ the prevalence of CT infection in asymptomatic men was of $4 \%$. Gillespie et a ${ }^{11}$ found a prevalence of $\mathrm{CT}$ infection in asymptomatic males of $2.5 \%$. A review in selected high-risk non-STI clinic venues in the United States ${ }^{7}$ showed median rates of asymptomatic CT infection to vary from $1.7 \%$ to $7.9 \%$ (overall $5.1 \%$ ), concluding that programs considering male CT screening should conduct local pilot programs to assess CT prevalence, risk factors, feasibility and cost. A similar study involving three United States STI clinics showed a prevalence of CT and NG infection in screening visits of $2.1 \%$ to $7.3 \%$ and $1.7 \%$ to $5.2 \%$ respectively. ${ }^{12}$ In this study, positivity for screen-visits was particularly high among young men (15-24 years), and those reporting more than 1 sex partner in the last 60 days. Another study in the United States ${ }^{13}$ found a $0-1.5 \%$ prevalence of NG infection in asymptomatic male. Non-hispanic black men have shown a higher prevalence of CT and NG infection in several studies. $9,14,15$

Concerning MSM, some studies have found relatively lower prevalence of asymptomatic urethral CT infection (2.3$2.7 \%){ }^{16-18} \mathrm{CT}$ infection has been found to represent $44 \%$ vs $10 \%$ of non-gonococcal urethritis in heterosexual and MSM, respectively. ${ }^{19}$

Previous studies concerning Portuguese STI Clinics reveal a prevalence of $\mathrm{CT}$ infection in asymptomatic male patients of $3.1 \%$ to $5.1 \% .5,20,21$ In the study by Travassos et al ${ }^{20}$, there was a $3 \%$ prevalence of CT genital infection in the group of MSM (symptomatic and asymptomatic) vs $6.3 \%$ in heterosexual men $(p=0.026)$. In the studies of Santo et $a^{21}$ and Pedrosa et al, ${ }^{5}$ the highest prevalence of infected men was in the 25-29 and 26-35 age groups, respectively. The latter included a smaller sample of attendees incorrectly referred to the clinic with a noninfectious genital dermatosis in which the prevalence of asymptomatic $\mathrm{CT}$ infection was much lower (0.9\%).

Data from our study is, therefore, in line with already published literature. Although the differences found in our study were not statistically significant, if a stricter profile of the male patient to be screened is necessary for economic reasons, then the subgroup of heterosexual young men in high-risk settings seems to be the most appropriate for screening when considering asymptomatic genital infection.

\section{CONCLUSION}

The possibility of diagnosing asymptomatic infections by CT and NG with NAAT in first-void urine allowed the implementation of routine screening in high-risk groups. Epidemiologic studies help to determine which groups benefit from routine screening. In our study, results support routine screening of $\mathrm{CT}$ in asymptomatic patients attending our STI Clinic, especially when considering heterosexual young men.

\section{REFERENCES}

1. Lanjouw E, Ossewaarde JM, Stary a, Boag F, van der Meijden WI. 2010 European guideline for the management of Chlamydia trachomatis infections. Int J STD AIDS. 2010;21:729-37.

2. Bignell C, Unemo M, European STI Guidelines Editorial Board. 2012 European guideline on the diagnosis and treatment of gonorrhoea in adults. Int J STD AIDS. 2013;24:85-92.

3. Workowski KA, Bolan GA. Sexually transmitted diseases treatment guidelines, 2015. MMWR Recomm Rep. 2015;64:1-137.

4. Barreiros H, Azevedo J, Santo I. Evolução da Infecção Por Neisseria gonorrhoeae numa População da Consulta de DST do Centro de Saúde da Lapa de 2007 a 2011. Rev Soc Port Dermatol Venereol. 2013;71:65-70.

5. Pedrosa AF, Azevedo F, Lisboa C. Screening for Chlamydia infection in a sexually transmitted infection clinic: a missed opportunity? Int J Dermatol. 2015;54:405-9.

6. Guedes R, Simões J, Azevedo F, Lisboa C. Chlamydia trachomatis and Neisseria gonorrhoeae infections in attendees of a Sexually Transmitted Diseases Clinic - A ten year trend analysis. Rev Soc Port Dermatol Venereol. 2012;70:91-7.

7. Rietmeijer C, Hopkins E, Geisler WM, Orr DP, Kent CK. Chlamydia trachomatis positivity rates among men tested in selected venues in the United States: a review of the recent literature. Sex Transm Dis. 2008;35(11 Suppl):S8-S18.

8. European Centre for Disease Prevention and Control. Chlamydia Control in Europe: Stockholm: ECDPC; 2014.

9. Simms I, Talebi A, Rhia J, Horner P, French RS, Sarah $R$, et al. The English National Chlamydia Screening Programme: variations in positivity in $2007 / 2008$. Sex Transm Dis. 2009;36:522-7.

10. Yeganeh O, Jeddi-tehrani M, Yaghmaie F, Kamali K, Zeraati $\mathrm{H}$, Shakhssalim N, et al. A survey on the prevalence of chlamydia trachomatis and mycoplasma genitalium infections in symptomatic and asymptomatic men referring to Urology Clinic of Labbafinejad Hospital, Tehran, Iran. Iran Red Crescent Med J. 2013;15:340-4.

11. Gillespie CW, Manhart LE, Lowens MS, Golden MR. 
Asymptomatic urethritis is common and is associated with characteristics that suggest sexually transmitted etiology. Sex Transm Dis. 2013;40:271-4.

12. Kohl K, Sternberg M, Markowitz L, Blythe M, Kissinger $P$, Lafferty $W$, et al. Screening of males for Chlamydia trachomatis and Neisseria gonorrhoeae infections at STD clinics in three US cities - Indianapolis, New Orleans, Seattle. Int J STD AIDS. 2004;15:822-8.

13. Gaydos CA, Kent CK, Rietmeijer CA, Willard NJ, Marrazzo JM, Chapin JB, et al. Prevalence of Neisseria Gonorrhoeae among men screened for Chlamydia Trachomatis in four United States cities, 1999-2003. Sex Transm Dis. 2006;33:314-9.

14. Miller WC, Ford C, Morris M, Handcock MS, Schmitz $\mathrm{JL}$, Hobbs MM, et al. Prevalence of chlamydial and gonococcal infections among young adults in the United States. JAMA. 2004;291:2229-36.

15. Marrazzo JM, White CL, Krekeler B, Celum CL, Lafferty WE, Stamm WE, et al. Community-based urine screening for Chlamydia trachomatis with a ligase chain reaction assay. Ann Intern Med. 1997;127:796-803.

16. Mimiaga MJ, Mayer KH, Reisner SL, Gonzalez A, Dumas $B$, Vanderwarker $R$, et al. Asymptomatic gonorrhea and chlamydial infections detected by nucleic acid amplification tests among Boston area men who have sex with

\section{GEIDST}

men. Sex Transm Dis. 2008;35:495-8.

17. Kent CK, Chaw JK, Wong W, Liska S, Gibson S, Hubbard $G$, et al. Prevalence of rectal, urethral, and pharyngeal chlamydia and gonorrhea detected in 2 clinical settings among men who have sex with men: San Francisco, California, 2003. Clin Infect Dis. 2005;41:67-74.

18. Mimiaga MJ, Helms DJ, Reisner SL, Grasso C, Bertrand T, Mosure DJ, et al. Gonococcal, chlamydia, and syphilis infection positivity among MSM attending a large primary care clinic, Boston, 2003 to 2004. Sex Transm Dis. 2009;36:507-11.

19. Dixon L, Pearson S, Clutterbuck DJ. Chlamydia trachomatis infection and non-gonococcal urethritis in homosexual and heterosexual men in Edinburgh. Int J STD AIDS. 2002;13:425-6.

20. Travassos AR, Costa JB, Azevedo J, Santo I. Prevalência de infecção genital por Chlamydia trachomatis na Consulta de Venereologia - Estudo descritivo relativo ao primeiro semestre de 2010. Rev Soc Port Dermatol Venereol. $2011 ; 69: 211-5$.

21. Santo I, Azevedo J, Nunes B, Gomes JP, Borrego MJ. Partner notification for Chlamydia trachomatis urogenital infections: eight years of patient referral experience in the major Portuguese sexually transmitted infections clinic, 2000-07. Int J STD AIDS. 2011 ;22:548-51. 